\title{
TEGANGAN RESIDU KEPING ARESTER SEBAGAI FUNGSI DARI CACAH KEPING ARESTER
}

\author{
Devia Eka Yunida \\ Balai Besar Pengembangan Latihan Kerja Dalam Negeri (BBPLKDN) \\ Kementerian Tenaga Kerja dan Transmigrasi Bandung-Jawa Barat \\ Email: devia_s2te_2011@mail. ugm. ac. id. \\ T. Haryono \\ Jurusan Teknik Elektro dan Teknologi Informasi \\ Fakultas Teknik Universitas Gadjah Mada \\ Email: thrharyono@gmail.com.
}

\begin{abstract}
Indonesia is a tropical area with high intensity lightning strike (repeatedly). The voltage produced by lightning by increasing the presence of sensitive loads, lightning can easily worsen the quality of consumer power is generated even if the voltage is relatively low. Lightning strikes can cause excessive voltage along the power lines. Propagation can cause a voltage surge on low voltage systems, especially low voltage can damage the equipment. maintenance and protection against lightning strikes are very necessary for the prevention and countermeasures against such damage. Arrester is a device which is currently intensively used by the public to protect the equipment from lightning strikes. Arrester is a device used to protect the system from lightning with a current danger to earth countermeasures against such damage. Arrester is a device which is currently intensively used by the public to protect the equipment from lightning strikes. Arrester is a device used to protect the system from lightning with a current danger to earth leaving a certain resistance value so the voltage of the system is not experiencing voltage spikes in the system. This research was conducted through the use of several laboratory-scale testing of major equipment such as high voltage generator, impulse voltage generator, and oscilloscope. Modifications using 220 volt low voltage arrester Merlin Gerin LTD with a maximum current of $6.5 \mathrm{kA}$ as one to four diseri arrester and arrester calculation equations for low voltage circuit series for more than four arrester. From the test results it is known that the characteristics of arrester residual voltage will rise when connected in series. Low voltage arrester can be used for higher voltage requirements by counting the number of arrester. The equation for the required number of series arrester overvoltage surge to cut the $y=0.694 x-0.106$. so that later if needed more than 4 pieces arrester, the residue voltage can be estimated through the formula.
\end{abstract}

Keywords: Arrester, Serial, Voltage, Residual.

\section{ABSTRAK}

Petir merupakan fenomena alam yang biasanya muncul pada musim hujan yaitu diawali dengan kilat cahaya yang sesaat kemudian diikuti suara menggelegar. Wilayah Indonesia berada di daerah khatulistiwa yang mempunyai iklim tropis dan kelembaban yang cukup tinggi. Hal ini yang menjadi faktor utama pembentukan petir. Penelitian mengenai kapasitas pemotongan tegangan residu arester 
tegangan rendah 220 volt ini dilakukan dengan metode pengujian skala laboratorium. Pengujian dilakukan dengan menggunakan peralatan pengujian tegangan tinggi yang terdiri dari beberapa rangkaian yang memiliki fungsi khusus. Secara keseluruhan sistem pengujian pada penelitian ini dengan menggunakan rangkaian pembangkit impuls tegangan, empat buah arester yang diseri, pembagi tegangan dan osiloskop. Kemudian arester diuji dari mulai arester tunggal, seri dua, seri tiga maupun seri empat. Rangkaian yang digunakan dalam pengujian adalah rangkaian impuls arus yang ada di Laboratorium Teknik Tegangan Tinggi UGM. Hasil yang diperoleh dari pengujian menunjukkan bahwa semakin banyak arester yang diserikan semakin besar tegangan residunya. Sehingga nantinya diharapkan dengan arester tegangan rendah yang apabila diseri dapat menggantikan fungsi dari arester tegangan tinggi apabila diperlukan. Rumus eksponensial untuk jumlah arester yang dibutuhkan untuk diseri diperoleh yaitu $\mathrm{y}=0$. 694x-0. 106.

Kata Kunci: Arester, Seri, Rangkaian Pembangkit Impuls Tegangan, Tegangan residu.

\section{PENGANTAR}

Petir merupakan fenomena alam yang biasanya muncul pada musim hujan yaitu diawali dengan kilat cahaya yang sesaat kemudian diikuti suara menggelegar. Wilayah Indonesia berada di daerah khatulistiwa yang mempunyai iklim tropis dan kelembaban yang cukup tinggi. Hal ini yang menjadi faktor utama pembentukan awan Cumulonimbus penghasil petir. Siklus tropis memindahkan panas dari khatulistiwa ke daerah lintang lebih tinggi ataupun lebih rendah sehingga kuantitas sambaran petir cukup besar. Sambaran petir tersebut dapat menyebabkan tegangan berlebih sepanjang saluran tenaga listrik. Perambatan surja dapat menyebabkan tegangan lebih pada sistem tegangan rendah terutama dapat merusak peralatan tegangan rendah.

Arester merupakan sebuah alat yang dewasa ini secara intensif digunakan oleh khalayak umum untuk melindungi peralatan akibat sambaran petir. Arester melindungi peralatan tenaga listrik dengan cara membatasi surja tegangan lebih yang datang dan mengalirkannya ke tanah. Arester menyediakan jalur bagi arus akibat sambaran petir maupun tegangan transient ke tanah dengan tingkat impedansi yang rendah sehingga tidak timbul tegangan lebih pada peralatan (Satriyadi dkk. , 2010).

Penelitian mengenai arester, baik itu pengujian arester tegangan tinggi maupun arester untuk peralatan tegangan rendah telah banyak diteliti. Terkhusus perlindungan terhadap peralatan tenaga listrik bertegangan rendah. kekuatan medan magnet, pembuatan magnet permanen, dan aplikasi magnet permanen telah banyak diteliti. Zoro dan Yaijing melakukan penelitian mengenai proteksi perangkat listrik pada jaringan tegangan rendah, yaitu menggunakan jenis arester MOV merupakan arester tegangan tinggi untuk melihat induksi dan konduksi gelombang elektromagnetik sambaran petir jaringan tegangan rendah pada daerah Gunung Tangkuban Perahu. Sedangkan Zoro menggunakan berbagai jenis power supply untuk mengetahui karakteristik sambaran petir terhadap peralatan elektronik rumah tangga, tetapi dalam penelitian ini tidak menekankan pada proteksi peralatan hanya pada kualitas sambaran pada nilai Imax dan Vmax (Zoro, 2009). Sedangkan pada penelitian Yaijing masih menggunakan arester dengan kapasitas kilo ampere yang sangat tinggi padahal hanya untuk memproteksi peralatan tegangan rendah, Conti menyajikan Perhitungan petir tegangan lebih pada jaringan distribusi difokuskan pada identifikasi, apakah sambungan listrik antara jaringan tegangan menengah dan jaringan tegangan rendah dengan menggunakan pemodelan Alternative Transient Program (ATP) bersamaan dengan transformator, arrester, dan sistem pembumian yang menghasilkan tegangan lebih beban sangat tergantung pada model beban diadopsi, yang menunjukkan kebutuhan 
model beban yang memadai untuk analisis yang akurat dari tegangan lebih petir pada jaringan tegangan rendah (Zoro, 2009; Yaijing dkk. ,2003; Conti, 2012). Sama halnya dengan Bassijuga menyajikan perhitungan kinerja evaluasi nilai-nilai arus dan daya diserap oleh surge protective devices (SPDs) terhubung dalam tegangan rendah jaringan distribusi overhead kawat terbuka dengan menggunakan Alternative Transient Program (ATP) berupa pemodelan komponen sistem meliputi karakteristik insulasi (tegangan terhadap waktu untuk breakdown) dari isolator utama dan sekunder dan model trafo distribusi frekuensi tinggi (Bassi dkk, 2002). Parameter yang dipertimbangkan dalam analisis, seperti resistensi tanah tiang dan konsumen, posisi sambaran petir, dan nilai puncak sambaran arus.

Pengujian dengan menggunakan perangkat bertegangan rendah pun telah dilakukan. Pada rujukan yang lain bahwa Hidaka mengklarifikasi hubungan antara resistansi pembumian surge arrester dan perilaku gelombang petir yang diamati dalam peralatan tegangan rendah dengan menggunakan analisis Electro-Magnetic Transient Program (Hidaka dkk, 2013). Hasilnya menunjukkan bahwa resistansi pembumian surge arrester dipasang pada transformator dapat ditingkatkan sampai batas tertentu tanpa penurunan tingkat proteksi petir dari peralatan tegangan rendah dengan pemasangan kawat pembumian secaraoverhead dan pemendekan interval antara poles dengan surja arester. Demikian pula dengan Yaijing melakukan penelitian mengenai proteksi petir untuk catu daya dari peralatan elektronik terkhusus pada pasokan listriknya dengan menggunakan pemodelan menggunakan perangkat berupa alat bantu equipment under test (EUT), power supply computer, monitor CRT, recorder, mobile phone, impulse generator, osiloskop, shunt, pembagi tegangan, isolatiom transformer, dan sebagainya. Data yang disajikan dalam makalah ini dapat memberikan referensi bagi situasi nyata. Sama halnya dengan yang dilakukan Yaijing (Yaijing dkk. , 2007). Leusenkamp melakukan pemodelan dengan menggunakan perangkat berupa Impulse Voltage Generator (IVG) atau Marx Generator untuk membuktikan bagaimana sebuah IVG mampu menbantu pengambilan data pada osilasi arus suatu perangkat (Leusenkamp dkk. , 2012).

Penelitian lain mengenai arester dilakukan berdasarkan penggunaan arester sebagai alat pelindung tegangan lebih surja pada peralatan listrik tegangan rendah dapat dipengaruhi oleh lokasi penempatan dan jumlah arester yang digunakan, resistansi pentanahan serta magnitude surja petir terhadap tegangan lebih pada peralatan listrik (Supardi dan Budiman, 2007). Supardi dan Budiman sama halnya dengan yang dilakukan oleh Yaijing dan kawankawan, yaitu melakukan penelitian dengan menggunakan arester MOV (metal oxide varistor) sebagai pelindung tegangan lebih surja pada peralatan listrik tegangan rendah pada instalasi listrik gedung $\mathrm{H}$ fakultas teknik UMS dengan memvariasikan faktor pengaruh lokasi dan jumlah arester, resistansi pertanahan serta magnitude surja petir (Yaijing dkk. , 2007). Akan tetapi, penelitian Supardi dan Budiman menyatakan bahwa untuk memperbaiki tingkat perlindungan bahaya sambaran petir diperlukan penambahan jumlah arester tegangan rendah (Supardi dan Budiman, 2007). Penelitian pengaruh jumlah arester juga dilakukan oleh Sugimoto dan He melalui penelitian pemasangan beberapa arester secara paralel dan melihat efektivitasnya terhadap instalasi perlindungan terhadap tegangan lebih surja petir (Sugimoto dkk. , 1999).

Zoro dan Yaijing melakukan penelitian mengenai proteksi perangkat listrik pada jaringan tengangan rendah. Yaijing menggunakan jenis arester MOV yaitu arester tegangan tinggi untuk melihat induksi dan konduksi gelombang elektromagnetik sambaran petir jaringan tegangan rendah 
pada daerah Gunung Tangkuban Perahu (Yaijin, dkk, 2007). Sedangkan Zoro dan kawan-kawan menggunakan berbagai jenis power supply untuk mengetahui karakteristik sambaran petir terhadap peralatan elektronik rumah tangga, tetapi dalam penelitian ini tidak menekankan pada proteksi peralatan hanya pada kualitas sambaran pada nilai Imax dan Vmax (Zoro, 2009). Sedangkan pada penelitian Yajing masih menggunakan arester dengan kapasitas kilo ampere yang sangat tinggi padahal hanya untuk memproteksi peralatan tegangan rendah (Yaijing dkk, 2007).

Kemudian Sapardi dan Budiman sama halnya dengan Yaijing dan kawankawan melakukan penelitian dengan menggunakan arester MOV (metal oxide varistor) sebagai pelindung tegangan lebih surja pada peralatan listrik tegangan rendah pada instalasi listrik gedung $\mathrm{H}$ fakultas teknik UMS dengan memvariasikan faktor pengaruh lokasi dan jumlah arester, resistansi pertanahan serta magnitude surja petir (Supardi dan Budiman, 2007; Yaijing dkk. , 2003). Akan tetapi, penelitian Sapardi dan Budiman menyatakan bahwa untuk memperbaiki tingkat perlindungan bahaya sambaran petir diperlukan arester tegangan rendah (Supardi dan Budiman, 2007).

Di masa sekarang ini kebutuhan energi listrik semakin meningkat sejalan dengan berkembangnya teknologi. Perkembangan yang pesat ini harus diikuti dengan perbaikan mutu energi listrik terutama keandalannya. Maka dari itu gangguan dalam penyaluran energi listrik harus diminalisisr terutama perlindungan terhadap sambaran petir makin digalakkan, tetapi banyak kalangan menyayangkan mahalnya harga sebuah arester dan hanya mampu dikonsumsi oleh kalangan menengah ke atas dan pemasangannya yang kurang familiar untuk khalayak umum.

Dalam penelitian ini, penulis mencoba untuk menggunakan arester tegangan rendah 220 volt merlin gerin LTD dengan arus maksimum mencapai 6,5 kA sebanyak satu hingga empat buah arester diseri, high voltage impulse generator, dan osiloskop. Melalui percobaan ini, nantinya diperoleh nilai sejauhmana arester tegangan rendah yang diseri mampu menggantikan fungsi arester tegangan tinggi yaitu untuk memotong tegangan lebih pada kapasitas yang tinggi dengan harga lebih rendah.

Tujuan penelitian ini adalah untuk menentukan penggunaan arester sesuai dengan BIL (basic impulse insulation level) system tegangan yang dipakai.

Penelitian mengenai kapasitas pemotongan tegangan residu arester tegangan rendah 220 volt ini dilakukan dengan metode pengujian skala laboratorium. Pengujian dilakukan dengan menggunakan peralatan pengujian tegangan tinggi yang terdiri dari beberapa rangkaian yang memiliki fungsi khusus. Secara keseluruhan sistem pengujian pada penelitian ini ditunjukkan pada gambar berikut.

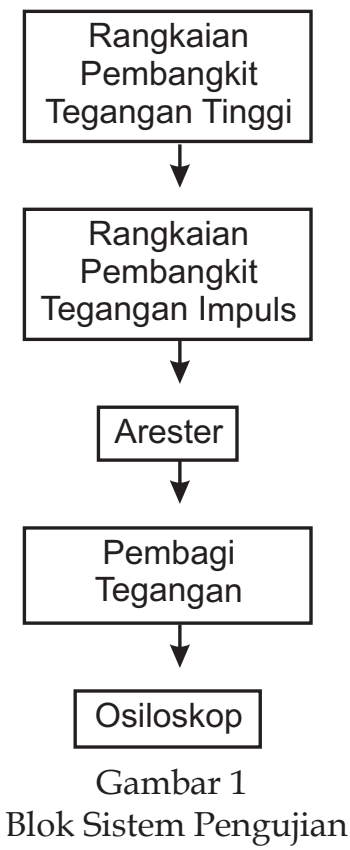

Rangkaian pembangkit impuls tegangan yang digunakan dalam pengujian adalah rangkaian impuls tegangan yang ada di Laboratorium Teknik Tegangan Tinggi UGM, yang skema pembangkit impuls tegangan 
dapat dilihat pada gambar nomor 2. Satu set blok sistem pengujian arester tersebut terdiri dari:

a. High Voltage Testing Device(pembangkit tegangan DC, penyearah gelombang $\mathrm{AC}$, panel kendali, pembagi tegangan, tongkat pentanahan),

b. rangkaian pembangkit tegangan impulse (kapasitor tegangan tinggi bernilai masing-masing $0.25 \mu \mathrm{F}$, sela bola, resistor tegangan tinggi, inductor tegangan tinggi),

c. rangkaian pembagi tegangan,

d. osiloskop.

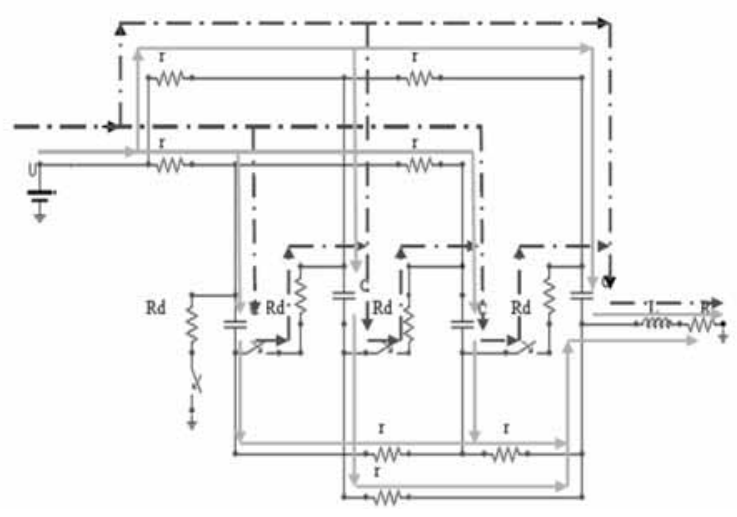

Gambar 2

Rangkaian Pembangkit Tegangan Impulse dan Aliran Arusnya

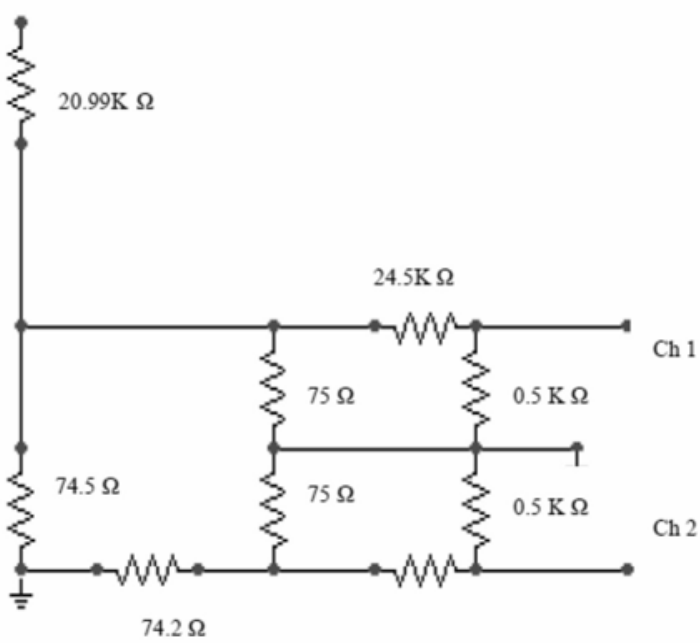

Gambar 3

Rangkaian Pembagi Tegangan
Pembagi tegangan berfungsi untuk memperkecil tegagan agar dapat diamati menggunakan alat ukur yang ada, dalam hal ini adalah osiloskop. Osiloskop memiliki kemampuan dalam membaca besar tegangan. Pengukuran dalam tegangan tinggi, level tegangan harus diturunkan agar osiloskop mampu untuk menunjukkan gelombang yang dihasilkan pada pengujian yang dilakukan. Terdapat dua buah pembagi tegangan pada rangkaian pembagi tegangan sesuai dengan Gambar nomor 3. Nilai perbandingan input dan output pembagi tegangan pertama sebagai berikut:

$$
(20990+74.5): 74.5=282.7: 1
$$

Sedangkan perbandingan pada pembagi tegangan kedua adalah:

$$
(24.5+0.5): 0.5=50: 1
$$

Jika kedua pembagi tegangan terhubung, maka tahanan $74.5 \Omega$ pada pembagi tegangan I terhubung secara paralel dengan tahanan $75 \Omega$ pada pembagi tegangan II, sehingga menjadi:

$$
(74.5 \times 75) /(74.5+75)=37.4 \Omega
$$

Sehingga perbandingan pembagi tegangan secara keseluruhan sebagai berikut:

$$
50 \times(20990+37.4):(37.4)= \pm 28100
$$

\section{Ketahanan Peralatan Listrik Tegangan Rendah terhadapSurja BIL (Basic Impulse Insulation Level)}

Nilai ketahanan isolasi dari sebuah peralatan sistem tenaga bila dilalui oleh impuls petir standar disebut dengan BIL. Ketahanan peralatan listrik terhadap tegangan residu berbeda-beda. Berdasarkan Standar Nasional Indonesia (SNI) 04-7021. 2. 1-2004, tentang "Peralatan Sistem dan Telekontrol" Syarat minimum tegangan tahanan isolasi untuk peralatan dengan uji ketahanan frekuensi daya $50 \mathrm{~Hz}$ dan uji impuls yang sesuai dengan Tabel 1 . 
Tabel 1

Klas Ketahanan Tegangan Perangkat Tegangan Rendah

\begin{tabular}{|c|c|c|}
\hline Klas & $\begin{array}{c}\text { Ketahanan } \\
\text { Tegangan Frekuensi } \\
\text { Daya (kV rms - } 60 \mathrm{~s})\end{array}$ & $\begin{array}{l}\text { 1,2/50 us tegangan } \\
\text { impulse } \mathrm{kV} \\
\text { puncak }\end{array}$ \\
\hline VW1 & 0,5 & 1 \\
\hline VW2 & 1 & 2 \\
\hline VW3 & 2,5 & 5 \\
\hline VWx & Khusus & Khusus \\
\hline
\end{tabular}

Sedangkan untuk ketahanan tegangan terhadap surja petir yang dispesifikasikan oleh IEC 60060 dan IEC 60664-1 memaparkan untuk kapasitas tegangan menengah yang biasa diaplikasikan pada industri di Indonesia. Nilai uji impuls yang digunakan untuk standarisasi penelitian ini dicuplik standarisasi IEC 60664-1.

Bahan yang digunakan pada penelitian ini adalah arester tegangan rendah 220 volt Imax 6,5 kA merek Merlin Gerin Multi 9 LTD (tipe lama dari Scneider PRD $8 \mathrm{kA}$ ) seperti ditunjukkan pada gambar nomor 4 dengan spesifikasi sebagai berikut :

Tabel 2

Spesifikasi Arester Tegangan Rendah 220 Volt

\begin{tabular}{l|l|l}
\hline No & Spesifikasi & Rincian \\
\hline 1. & Jumlah Kutub & 1 pole \\
\hline 2. & I imp $(8 / 20)$ & $5 \mathrm{kA}$ \\
\hline 3. & I max $(8 / 20)$ & $6,5 \mathrm{kA}$ \\
\hline 4. & Tegangan Nominal & $280 \mathrm{~V}$ \\
\hline 5. & $\begin{array}{l}\text { Tegangan Operasi } \\
\text { Maksimum Uc }\end{array}$ & $240 \mathrm{~V}$ \\
\hline 6. & Tegangan Proteksi Up & $1 \mathrm{kV}$ \\
\hline
\end{tabular}

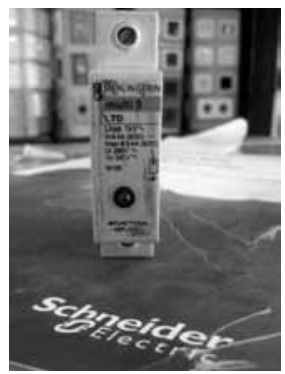

Gambar4

Arester Merlin Gerin Multi 9 LTD
Gambar nomor 5 merupakan langkahlangkah pengujian, langkah pertama yaitu melakukan setting perangkat rangkaian pembangkit tegangan. Setelah itu dilakukan pengujian terhadap tegangan masukan dimana yangdimaksudkanadalah tegangan gangguan yang merupakan rekayasa dari sambaran petir. Kemudian dilakukan penyimpanan grafik tegangan masukan pada osiloskop. Setelah tegangan masukan mencukupi, maka dilakukan pengujian tegangan residu yang mampu dijangkau oleh arester baik saat dalam keadaan tunggal maupun seri 2 , seri 3 , dan seri 4. Lalu langkah terakhir adalah menyimpan data osiloskop sehingga diketahui kapasitas arester dalam memotong tegangan (tegangan residu arester).

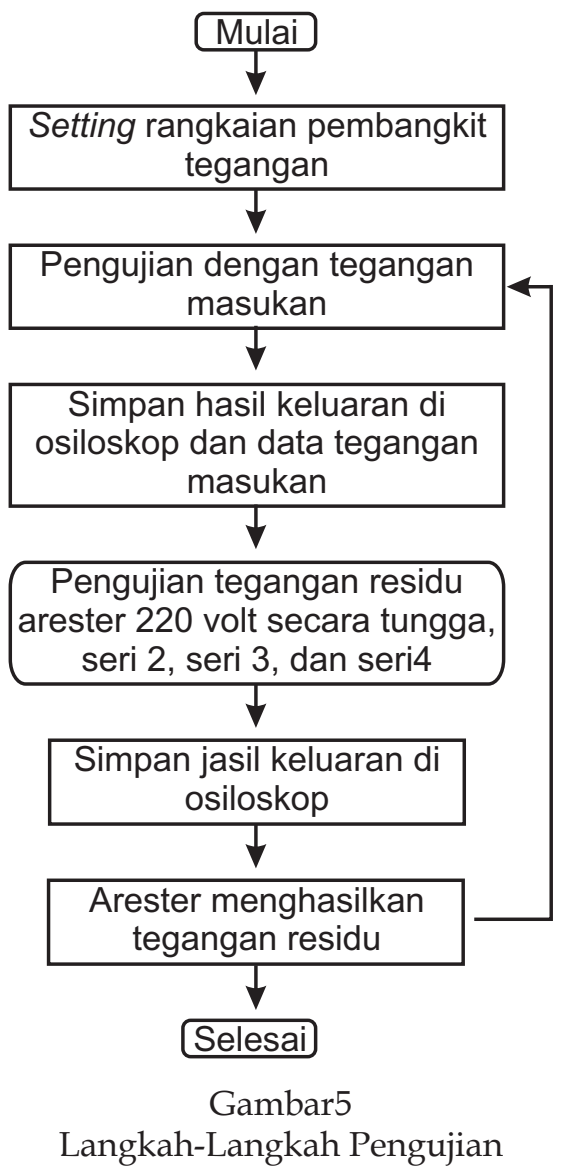

\section{PEMBAHASAN}

Variasi jumlah pemasangan seri arester tegangan rendah 220 volt menghasilkan 
berbagai nilai tegangan residu yang menyatakan kapasitas potong dari sebuah arester terhadap sambaran petir.

Tabel 3 dan Gambar 6 menunjukkan keadaan arester saat tidak diseri dan disambungkan ke pembangkit impuls tegangan tinggi dalam keadaan tunggal. Dari keempat arester dengan spesifikasi yang sama, dengan tegangan gangguan sebesar 1,07904 kV maka akan dihasilkan tegangan residu yang sama yaitu $0,62944 \mathrm{kV}$.

Table 4 dan Gambar 7 menunjukkan dua buah arester tegangan rendah dengan spesifikasi yang sama dihubungkan dengan pembangkit impuls tegangan tinggi. Dari keenam variasi penserian dari empat buah arester (A1,A2, A3, A4) dengan tegangan gangguan sebesar 1,394 $\mathrm{kV}$ dihasilkan tegangan residu yang sama yaitu $1,16896 \mathrm{kV}$.

Tabel 5 dan Gambar 8 menunjukkan tiga buah arester tegangan rendah dengan spesifikasi yang sama dihubungkan dengan pembangkit impuls tegangan tinggi. Dari keempat variasi penserian dari empat buah arester (A1,A2, A3, A4) dengan tegangan gangguan sebesar 3,3158 $\mathrm{kV}$ dihasilkan tegangan residu yang sama yaitu 2,0794 kV.

Tabel 6 dan Gambar 9 menunjukkan empat buah arester tegangan rendah dengan spesifikasi yang sama dihubungkan dengan pembangkit impuls tegangan tinggi. Variasi penserian dari empat buah arester (A1,A2, A3, dan A4) dengan tegangan gangguan sebesar 4,6646 kV dihasilkan tegangan residu yang sama yaitu 2,6414 kV.

Tabel 3

Tegangan Residu Empat Buah Arester Tunggal

\section{A. ARESTER TUNGGAL}

TEGANGAN CHARGING $=36 \mathrm{kV}$

TEGANGAN GANGGUAN $=1.07904 \mathrm{kV}$

\begin{tabular}{l|l|l}
\hline Arester & \multicolumn{1}{|c|}{$\begin{array}{c}\text { Tegangan } \\
\text { Gangguan }\end{array}$} & \multicolumn{1}{|c}{$\begin{array}{c}\text { Tegangan } \\
\text { Residu }\end{array}$} \\
\hline A1 & $1.07904 \mathrm{kV}$ & $0.62944 \mathrm{kV}$ \\
\hline A2 & $1.07904 \mathrm{kV}$ & $0.62944 \mathrm{kV}$ \\
\hline A3 & $1.07904 \mathrm{kV}$ & $0.62944 \mathrm{kV}$ \\
\hline A4 & $1.07904 \mathrm{kV}$ & $0.62944 \mathrm{kV}$ \\
\hline
\end{tabular}

Tabel 4

Tegangan Residu Arester Seri Dua

B. ARESTER SERI-2

TEGANGAN CHARGING $=46 \mathrm{kV}$

TEGANGAN GANGGUAN=1.394kV

\begin{tabular}{l|l|l}
\hline Arester & \multicolumn{1}{|c|}{$\begin{array}{c}\text { Tegangan } \\
\text { Gangguan }\end{array}$} & \multicolumn{1}{|c}{$\begin{array}{c}\text { Tegangan } \\
\text { Residu }\end{array}$} \\
\hline $\mathrm{A} 1+\mathrm{A} 2$ & $1.39376 \mathrm{kV}$ & $1.16896 \mathrm{kV}$ \\
\hline $\mathrm{A} 1+\mathrm{A} 3$ & $1.39376 \mathrm{kV}$ & $1.16896 \mathrm{kV}$ \\
\hline $\mathrm{A} 1+\mathrm{A} 4$ & $1.39376 \mathrm{kV}$ & $1.16896 \mathrm{kV}$ \\
\hline $\mathrm{A} 2+\mathrm{A} 3$ & $1.39376 \mathrm{kV}$ & $1.16896 \mathrm{kV}$ \\
\hline $\mathrm{A} 2+\mathrm{A} 4$ & $1.39376 \mathrm{kV}$ & $1.16896 \mathrm{kV}$ \\
\hline $\mathrm{A} 3+\mathrm{A} 4$ & $1.39376 \mathrm{kV}$ & $1.16896 \mathrm{kV}$ \\
\hline
\end{tabular}

Tabel 5

Tegangan Residu Arester Seri Tiga

C. ARESTER SERI-3

TEGANGAN CHARGING $=23 \mathrm{kV}$

TEGANGAN GANGGUAN=3.3158 kV

\begin{tabular}{c|l|l}
\hline \multicolumn{1}{c|}{ Arester } & \multicolumn{1}{|c}{$\begin{array}{c}\text { Tegangan } \\
\text { Gangguan }\end{array}$} & $\begin{array}{c}\text { Tegangan } \\
\text { Residu }\end{array}$ \\
\hline $\mathrm{A} 1+\mathrm{A} 2+\mathrm{A} 3$ & $3.3158 \mathrm{kV}$ & $2.0794 \mathrm{kV}$ \\
\hline $\mathrm{A} 1+\mathrm{A} 2+\mathrm{A} 4$ & $3.3158 \mathrm{kV}$ & $2.0794 \mathrm{kV}$ \\
\hline $\mathrm{A} 1+\mathrm{A} 3+\mathrm{A} 4$ & $3.3158 \mathrm{kV}$ & $2.0794 \mathrm{kV}$ \\
\hline $\mathrm{A} 2+\mathrm{A} 3+\mathrm{A} 4$ & $3.3158 \mathrm{kV}$ & $2.0794 \mathrm{kV}$ \\
\hline
\end{tabular}

Tabel 6

Tegangan Residu Arester Seri Empat

D. ARESTER SERI-4

TEGANGAN CHARGING $=33 \mathrm{kV}$

TEGANGAN GANGGUAN $=4.66 \mathrm{kV}$

\begin{tabular}{c|c|c}
\hline Arester & $\begin{array}{c}\text { Tegangan } \\
\text { Gangguan }\end{array}$ & $\begin{array}{c}\text { Tegangan } \\
\text { Residu }\end{array}$ \\
\hline $\mathrm{A} 1+\mathrm{A} 2+\mathrm{A} 3+\mathrm{A} 4$ & $4.6646 \mathrm{kV}$ & $2.6414 \mathrm{kV}$ \\
\hline
\end{tabular}

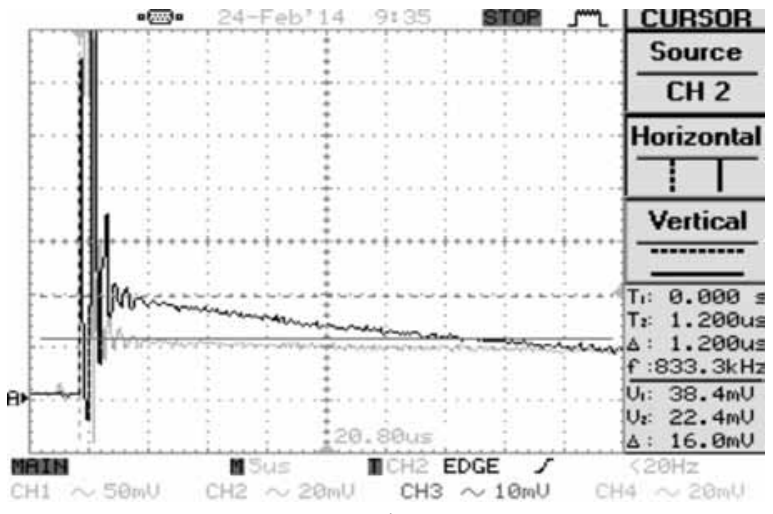

Gambar 6

Tegangan Residu Arester Tunggal 


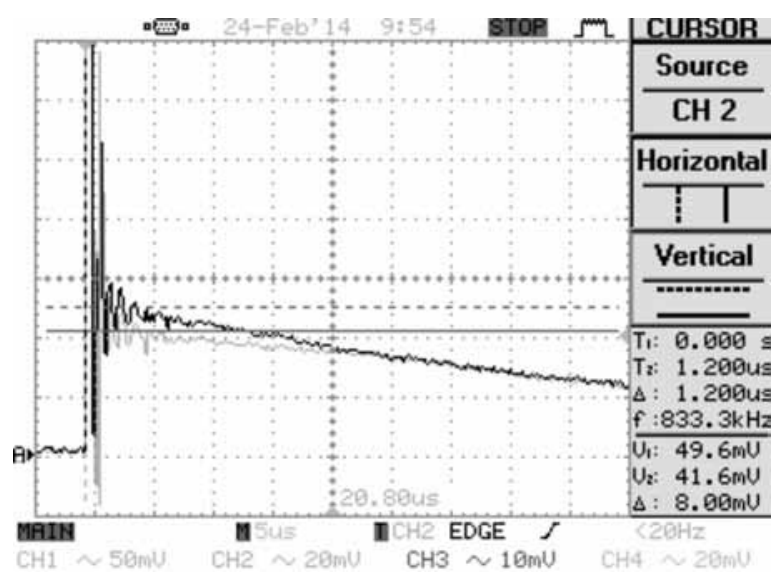

Gambar 7

Tegangan Reidu Arester Seri-2

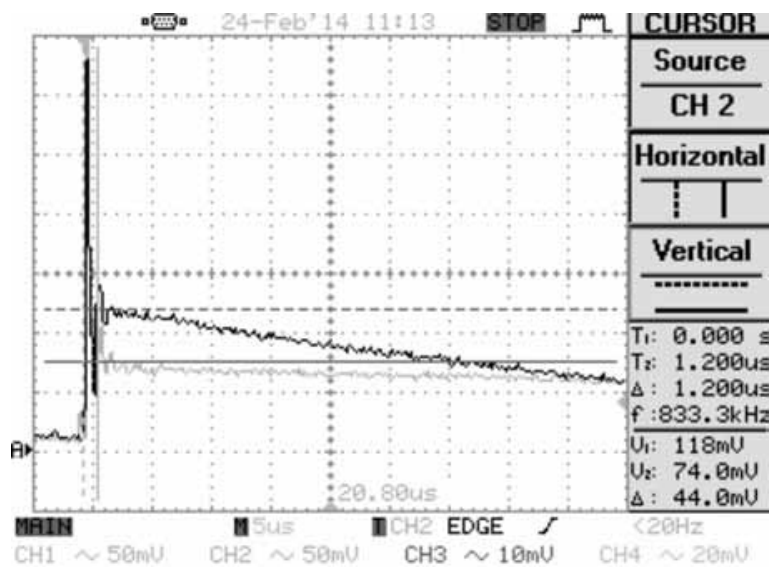

Gambar 8

Tegangan Residu Arestes Seri-3

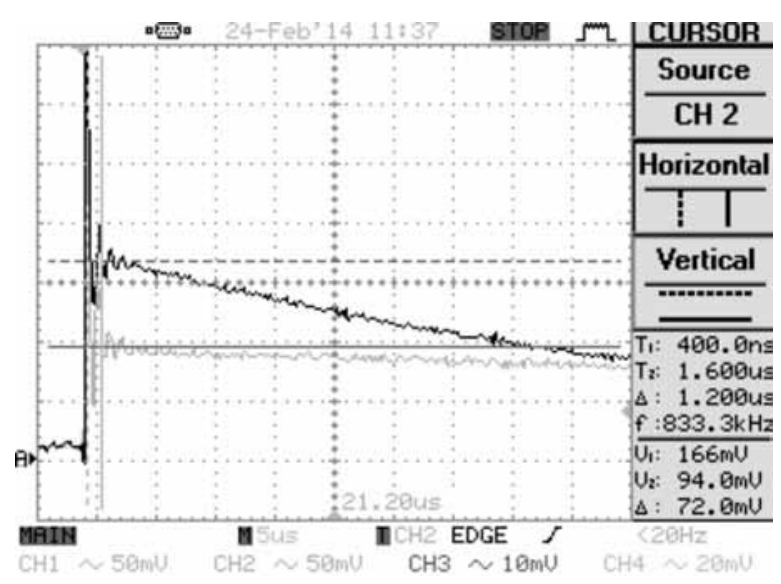

Gambar 9

Tegangan Residu Arester Seri-4
Terdapatnya osilasi pada output dari tegangan residu dan tegangan impuls yang disebabkan adanya lilitan yang terdapat pada rangkaian pembagi tegangan, sesuai dengan rumus :

$$
\mathrm{f}=\frac{1}{2 \pi \sqrt{\mathrm{LC}}}
$$

apabila semakin banyak lilitan dapat menimbulkan frekuensi osilasi pada gelombang dan menjadi noise pada awal gelombang terbentuk.

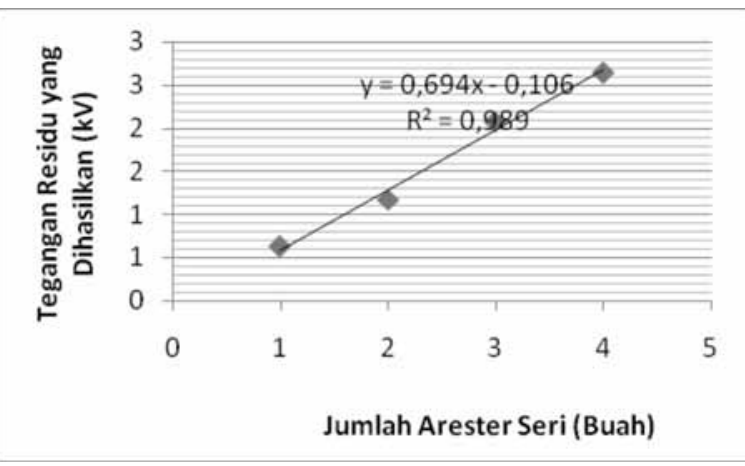

Gambar 10

Regresi Linier Jumlah Arester berbanding Tegangan Residu

Sesuai gambar 10, Rumus regresi linier untuk jumlah arester yang dibutuhkan untuk diseri diperoleh yaitu :

$$
y=0,694 x-0,106
$$

dengan $R^{2}=0,989$. sehingga nantinya apabila diperlukan lebih dari 4 buah arester,dapat diperkirakan tegangan residunya melalui rumus tersebut.

\section{SIMPULAN}

Dari hasil pengujian dan pembahasan yang telah dilakukan dapat diambil beberapa kesimpulan sebagai berikut: Penelitian yang telah dilakukan untuk empat buah arester tunggal dengan spesifikasi yang sama dihasilkan tegangan residu sebesar 0,62944 $\mathrm{kV}$, untuk empat buah arester seri dua dengan spesifikasi yang sama dihasilkan tegangan residu sebesar 1,168960 kV, 
untuk empat buah arester seri tiga dengan spesifikasi yang sama dihasilkan tegangan residu sebesar $1,73283 \mathrm{kV}$, untuk empat buah arester seri empat dengan spesifikasi yang sama dihasilkan tegangan residu sebesar 2,3543 kV, sehingga dari hasil data tersebut disimpulkan karakteristik tegangan residu arester akan naik apabila dihubungkan secara seri sebagai berikut: (a) Arester tegangan rendah dapat digunakan untuk tegangan yang lebih tinggi dengan menghitung kebutuhan jumlah arester. (b) Persamaan untuk jumlah arester seri yang dibutuhkan untuk memotong tegangan lebih surja yaitu $\mathrm{y}=0,694 \times-0,106$ dengan $\mathrm{R}^{2}=$ 0,989 . sehingga nantinya apabila diperlukan lebih dari 4 buah arresterdapat diperkirakan tegangan residunya melalui rumus tersebut.

\section{Ucapan Terima Kasih}

Penulis mengucapkan terima kasih kepada Dosen Pembimbing dan Laboran dari Laboratorium Tegangan Tinggi Jurusan Teknik Elektro karena telah membimbing dan membantu penulis dalam menyelesaikan penelitian ini.

Terima kasih disampaikan juga kepada Tim Jurnal Teknosains yang telah meluangkan waktu untuk membantu publikasi penelitian ini.

\section{DAFTAR PUSTAKA}

IGN Satriyadi H. , S. Anam, R. Wahyudi, H. Kijoyo," Analisis Kinerja Arester Tegangan Tinggi 150 $\mathrm{kV}$ Menggunakan Power System Computer Aided Design",Journal of Electrical and Electronics Engineering, vol. 8, no. 1, April 2010, hal. 25-30.

R. Zoro, "Induksi dan Konduksi Gelombang Elektromagnetik Akibat Sambaran Petir pada Jaringan Tegangan Rendah", Makara Teknologi, vol. 13, no. 1, April 2009, hal. 25- 32.

C. Yaijing, Z. Wenjun, H. Ruidong, Z. Luxing, "Experimental Study of
Lighting Characteristic of Electronic Equipment's Power Supply", Proceedings of the World Congress Engineering,vol. I, July 2003.

Conti, A. D. , Silveira, F. H. , Visacro, S. , 2012. Lighting Overvoltages on Complex Low-Voltage Distribution Networks. Electric Power Systems Research 85, 7-15.

Bassi, W. , Janiszweski, J. M. , 2002. Evaluation of Currents and Charges in Low-Voltage Surge Arresters due to Lighting Strikes. IEEE 369.

Hidaka, T. , Kazuyuki, I. , Asakawa, A. ,Shiota, K. , 2013. Relationship between Grounding Resistance Connected to Surge Arresters and Lightning Surge Behavior Observed in LowVoltage Equipment. International Symposium on Lightning Protection (XII SIPDA) 2013.

Yaijing, C. , Wenjun, Z. , Ruidong, H. , Luxing, Z. , 2007. Experimental Study on Lightning Characteristics of Electronic Equipment's Power Supply. Proceedings of the World Congress on Engineering I.

Leusenkamp, M. B. J. , 2012. Impulse Voltage Generator Design and the Potential Impact on Vaccum Interrupter Deconditioning. XXVth Int. Symp. on Discharge and Electrical Insulation in Vacuum 453-456.

Supardi, A. , Budiman, A. , 2007. Kinerja Arester MOV (metal Oxide Varistor) sebagai Alat Pelindung Tegangan Lebih Surja pada Peralatan Listrik Tegangan Rendah. Publikasi Ilmiah UMS LPPM UMS.

Yaijing, C. , Wenjun, Z. , Ruidong, H. , Luxing, Z. , 2007. Experimental Study on Lightning Characteristics of Electronic Equipment's Power Supply. Proceedings of the World Congress on Engineering I. 
Sugimoto, H. , Yokohama, S. , Nakada, K. , 1999. Effectiveness of Installing Two Pairs of Distribution Surge Arresters in Parallel. High Voltage Engineering Symposium.

He, J. , Hu, J. , Chen, Y. , Chen, S. , Zeng, R. , 2009. Minimum Distance of Lightning Protection Between Insulator String and Line Surge Arrester in Parallel.
IEEE Transactions on Power Delivery 24, 656-663.

Zoro, R. , 2009. Induksi dan Konduksi Gelombang Elektromagnetik Akibat Sambaran Petir pada Jaringan Tegangan Rendah. MAKARA TEKNOLOGI 13 No. 1, 25-32.

Puriyanto, R. D. , 2013. Pengaruh Front Time Terhadap Karakteristik Perlindungan Arester ZnO Dan SiC 18 KV. 